\title{
Factors That Can Be Predictors of Carbon Emissions Disclosure
}

\author{
Arini Nur Khulil Jannah ${ }^{1}$ and I Made Narsa ${ }^{2}$ \\ ${ }^{1,2}$ Faculty of Economic and Bussiness, Airlangga University, Surabaya \\ Email Address: \\ arini.nur.khulil-2017@feb.unair.ac.id
}

\begin{abstract}
This research is to analyze the role of ISO 14001, performance environment index PROPER, environmental committee, and foreign diversity to carbon emissions disclosure in the plantation company that registered at the Indonesian stock exchange of 2013 to 2019. The data used was 77 companies. The testing of hypotheses uses multiple linear regression with a minimal significance of 5\%. this research proves that there is four a variable that has a significant result on the disclosure of the carbon emission in plantation company that is ISO 14001, performance environment index PROPER, environmental committee and Foreign diversity. Three variables have no effect on the disclosure of carbon emissions that is age company, leverage, and return of equity. This research can be used stakeholder to see the company's responsibilities through their environment to ensure there is no risk in the company's future performance before reaching their investment decision.
\end{abstract}

Keywords: ISO 14001, environmental accounting, carbon emission disclosure.

\begin{abstract}
Abstrak: Penelitian ini bertujuan untuk menganalisis peran ISO 14001, PROPER indeks lingkungan kinerja, komite lingkungan dan foreign diversity terhadap pengungkapan emisi karbon pada perusahaan perkebunan yang terdaftar di Bursa Efek Indonesia tahun 2013 hingga 2019. Data yang digunakan adalah 77 perusahaan. Pengujian hipotesis menggunakan regresi linier berganda dengan tingkat signifikansi 5\%. Hasil uji penelitian membuktikan bahwa ada empat variabel yang berpengaruh signifikan terhadap pengungkapan emisi karbon pada perusahaan perkebunan yaitu ISO 14001, indeks kinerja lingkungan PROPER, komite lingkungan dan foreign diversity. Ada tiga variabel yang tidak berpengaruh terhadap pengungkapan emisi karbon yaitu umur perusahaan, leverage dan retun of equity. Penelitian ini dapat digunakan stakeholder untuk melihat tanggung jawab perusahaan melalui lingkungannya untuk memastikan tidak ada risiko terhadap kinerja perusahaan di masa depan sebelum mengambil keputusan investasi.
\end{abstract}

Kata Kunci: ISO 14001, akuntansi lingkungan, pengungkapan emisi karbon.

\section{INTRODUCTION}

Despite the acceleration and success of the world's technology and industry, several inevitable adverse effects can be attributed to the drastic climate changes (Stern, 2008; Yunus et al., 2016). Climate change is related to the decreasing environmental quality along with industrial development, carbon retention, and increasing carbon emission from the 
entities and other human activities that accumulate over time (Iswati, 2017). Extensive media coverage on this issue, as well as growing awareness from the government, consumers, financial institutions, and the public; drive companies to consider strategic decisions upon climate change (Sprengel and Busch, 2011; Weinhofer and Hoffmann, 2010; Yunus et al., 2016). Previous studies discovered companies voluntarily informed the environmental impact and disclosed the carbon emission rate to fulfill the regulation, which also ensures the operational continuity of companies and companies' responsibility to stakeholders (Collier, 2008). Companies' duty in mitigating climate change and environmental impacts is by analyzing, measuring, recording, and reporting the carbon emission rate (Kalu et al., 2016).

In 1993, European Union gave information on carbon emission disclosure by publishing Environmental Management and Audit Scheme as part of the Environmental Management System (EMS) certification based on a specific guideline in 1996 (Orcos and Palomas, 2019). To support that, the International Standardization Organization (ISO) published an environmental management certification that companies can voluntarily accomplish, i.e., ISO 14001 (Hettige et al., 2000). ISO 4001 is an international standard environmental management system that contains requirements for structured management approaches for environment conservation to ensure that all process in a company has fulfilled its commitment to the environment (Orcos and Palomas, 2019). ISO 14001 helps companies to control and mitigate the environmental impacts, and also supports companies' legitimacy from external parties (Orcos and Palomas, 2019). One requirement for ISO 14001 certification is providing documented information on environmental aspects that also include carbon emission disclosure analysis, both quantitative and qualitative (ISO., 2015). A previous study also discovered companies that implemented the internal management procedures based on ISO 14001 reported better carbon emission disclosures and environmental performance (Hettige et al., 2000; Ikram et al., 2019; Orcos and Palomas, 2019).

Environmental performance is related to carbon emission disclosure. (Luo et al., 2013) stated that environmental performance is one way to measure how companies take responsibility for their surroundings. The Indonesian government through the Ministry of the Environment has made an environmental performance measurement system, i.e., PROPER (Program Penilaian Peringkat Kinerja Manajemen Lingkungan) that is used annually to score the environmental performance of companies based on the criteria (Iriyanto and Nugroho, 2014). The system is in line with Presidential Regulation No. 61 (2011) about the national action plan for reducing greenhouse gas emissions and Presidential Regulation No. 71 (2011) about the implementation of greenhouse gas inventory. Both regulations are published to support the targeted emission data inventory due to Indonesia's involvement in Kyoto Protocol, i.e. targeted carbon emission rate decrement of $29 \%$ in 2030 and zero or clean emission in 2050 (Freedman and Jaggi, 2011). (Prafitri and Zulaikha, 2016) also stated that higher environmental performance ranks reflect better carbon emission disclosures.

One crucial factor in increasing carbon emission disclosure is companies' environmental committee. Company environmental committees shall apply strategies and practices to measure and report the greenhouse gas emission rate (Ashforth and Gibbs, 1990). Companies establish environmental committees as their responsibility to manage the environmental risk, including reputation risk and stakeholder's legitimacy threat (Ferreira et al., 2013; Rankin et al., 2011; Yunus et al., 2016). The primary responsibility of the 
environmental committee is to report the company's sustainability report and other information related to environmental impacts. Environmental committees can be a predictor for carbon emission rate disclosure because companies with environmental committees can give more information and increase the quality of carbon emission disclosure.

The relationship between foreign diversity to carbon emission disclosure is rarely studied (Kılıç and Kuzey, 2019). Foreign diversity is the diversity of foreign commissaries in one company. Commissaries' diversity is one variable in a company, other than skills, personalities, learning styles, nationalities, backgrounds, educations, ages, and experiences (Coffey and Wang, 1998). The supervisory function of foreign commissaries is expected to improve the management's ability in recognizing the needs and interests of various stakeholders, especially in terms of carbon emission disclosure (Harjoto, 2019). Therefore, there should be more comprehensive studies on whether foreign diversity is a predictor for improving carbon emission disclosure.

When companies raise their awareness of the environmental management system, environmental performance, and environmental committees, the quality of their carbon emission reports also improves (Yunus et al., 2016). Legitimacies. Usually, companies invest more in green innovations (Luo et al., 2013). Companies' initiative is also important in improving carbon emission disclosure. Companies put more effort into establishing environmental committees (Yunus et al., 2016). Although many past researchers think carbon emission is important (Liao et al., 2015), many also argue that companies report carbon emission only to improve their images without proper attention to environmental sustainability (Aerts and Cormier, 2009). (Blackman, 2012) stated that ISO 14001 is only a symbol to improve companies' legitimacy (Vílchez, 2017) and only focuses on the process not the result, i.e., decreasing carbon emission rate and improving environmental performance (Bansal and Hunter, 2003). Although there are many contradicting views, ISO 14001 is still the most used standard in many companies to evaluate their environmental performances (Sartor et al., 2019). The purpose of this research is to fulfill the inconsistent result gap in studies regarding the relationship between ISO 14001, environmental performance, and environment committees in increasing carbon emission disclosure by addressing inter-variables relationship. The relationship between foreign diversity and carbon emission disclosure is also analyzed in this study. Currently, no study discusses the relationship between those variables with emission carbon disclosures in plantation companies in Indonesia.

\section{THEORETICAL REVIEW}

Legitimacy Theory was first mentioned by (Dowling and Pfeffer, 1975) illustrates the difference between the values adopted by companies and society. This difference, known as the legitimacy gap, may threaten companies. The legitimacy gap occurs because of companies' insensitivity to the impacts from companies' activities and community expectations of the company and only focuses on generating maximum profit (Lindawati \& Puspita, 2015). (Guthrie and Parker, 1989) stated that company disclosure is a reaction to environmental pressures (economic, social, and political) to legitimize the companies' existence and behavior. Based on legitimacy theory, organizations build environmental legitimacy based on their responsible actions to the environment and society for their past actions (Ferreira et al., 2013; Lindblom, 1994). ISO 14001, environmental performance, 
environmental committees, and foreign diversity are several efforts from companies to overcome the legitimacy gap. These efforts are expected to serve as predictors in increasing the quality of the environmental impacts report, especially related to carbon emission disclosure (Yunus et al., 2016). This relationship shows that companies continually raise their awareness of the environment and surrounding society to improve their images and avoid the legitimacy gap (Bansal and Hunter, 2003).

Carbon emission disclosure is a disclosure practice to stakeholders and the public which comprises the company's activities and the impact of those activities (Choi et al., 2013). Global warming is currently becoming a more important political and business issue in various countries across the globe (Stern, 2008; Yunus et al., 2016). Many challenges arise from global warming, one of them to ensure all entities understand and communicate their contributions to global warming from carbon emission. This stems from the understanding that greater awareness of the problems can lead to more environmentally responsible strategies and mandatory environmental disclosures, including carbon emission disclosure (Choi et al., 2013; Gray et al., 1995; Yunus et al., 2016).

ISO 14001. is an international standard for an Environmental Management System (EMS) that contains requirements for the structural management approach for environmental protection (Orcos and Palomas, 2019). ISO 14001 results from collective efforts from many countries to replace numerous environmental standards, and it can be easily applied by multinational companies (Quazi et al., 2001). (Adams, 2002) stated that ISO 1400 shows a better environmental management system to produce more environmentally friendly products that consumers can accept. To get ISO 14001 certification, companies have to identify the significant factors, e.g. carbon emission, energy consumption, and water consumption. Companies also have to implement a management program to control and improve environmental performance. External auditors will review companies' environmental management systems to grant them ISO 14001 certification (Di Giacomo et al., 2017).

Environmental performance is the result that can be measured using an environmental management system that is related to the control of environmental aspects (Luo et al., 2013). The environmental performance report tests environmental performance (Dawkins and Fraas, 2011). Scoring is come based on the report, the higher the score of environmental performance, the higher the carbon emission disclosure (Iriyanto and Nugroho, 2014). In this study, the environmental performance is evaluated using five performance rank in PROPER (Program Penilaian Peringkat Kinerja Manajemen Lingkungan) gold rank as the highest score and black rank as the lowest score. This program was made as an environmental performance measurement system by The Indonesian government through the Ministry of the Environment. environmental performance PROPER that is used annually to score the environmental performance of companies based on some criteria (Iriyanto and Nugroho, 2014).

The environmental committee is a department formed by the company responsible for managing and releasing information on the company's environmental risks, including those related to environmental reputation risks and threats to stakeholder legitimacy (Ferreira et al., 2013; Rankin et al., 2011; Yunus et al., 2016). Corporate environmental committees 
motivate companies to implement strategies and practices for measuring and reporting levels of greenhouse gas emissions (Ashforth and Gibbs, 1990). Environmental committees manage strategies for environmental performance improvement and corporate carbon emissions disclosure to ensure that the disclosed information will not negatively affect companies' legitimacy and reputation.

Foreign diversity in this study refers to board diversity. Board diversity is one variable in a company, other than skills, personalities, learning styles, nationalities, backgrounds, educations, ages, and experiences (Coffey and Wang, 1998). It has become an important component of corporate governance structures (Barako and Brown, 2008). Past discussion regarding the impact of board gender diversity on carbon emissions disclosure mainly applies to the diversity of council nationalities. Diversity affects carbon emissions disclosure because, first, diversity causes different perspectives, ideas, and information into board discussions, thus enhances the company's ability to reach better and more effective decisions (Estélyi and Nisar, 2016). Second, board diversity increases the board's ability to recognize the needs and interests of different stakeholder groups (Harjoto et al., 2019).

\section{Hypothesis and Analysis Model.}

ISO 14001 Impact on Carbon Gas Emission Disclosure. ISO 14001 is an international standard environmental management system that determines the requirements for a structured management approach as environmental protection (Orcos and Palomas, 2019). ISO 14001 environmental management system standard is the common standard used by companies to assess their environmental performance (Sartor et al., 2019). This is because ISO 14001 requires the documentation of the company's activities and processes to identify the environmental regulations that should be complied with by the company (Di Giacomo et al., 2017). One requirement for ISO 14001 certification is providing documented information on environmental aspects that also include carbon emission disclosure analysis, both quantitative and qualitative (ISO., 2015) ISO 14001 requires consistency and commitment to comply with all environmental regulations that have been set and also helps companies to control and improve environmental impacts and helps companies gain legitimacy (Orcos and Palomas, 2019). The company should establish an evaluation when any inconsistencies with regulations especially those related to environmental impact, are detected by the external team (ISO 14001 auditors). Hence, the following hypothesis is proposed:

H1: Companies with ISO 14001 will have a higher level of carbon emission disclosure.

Environmental Performance Impact on Carbon Gas Emission Disclosure. Environmental performance is a measurement of how the company is responsible for its surrounding environment (Luo et al. (2013). The Indonesian government through the Ministry of the Environment has created a company environmental performance rating system called PROPER (Program Penilaian Peringkat Kinerja Manajemen Lingkungan) which annually rates the company's environmental performance through several predetermined criteria (Iriyanto and Nugroho, 2014). One of the criteria for proper environmental performance (Indonesia, 2014) is to show data of water pollution loads calculation, carbon emissions loads, and access to data on environmental impacts. The higher 
the PROPER environmental performance rating score of the company, the more detailed and the higher the quality of the carbon emission disclosure indicators (Prafitri and Zulaikha, 2016). A good company's environmental performance has a proactive strategy and this can motivate companies to voluntarily disclose information on activities and impacts on the environment (Clarkson et al., 2008; Prafitri and Zulaikha, 2016). A good environmental performance PROPER rating is also company legitimacy to convince stakeholders that the companies care and are willing to provide information on environmental impacts. Thus, the following hypothesis is suggested.

H2: Companies with high environmental performance will have a higher level of carbon emission disclosure.

Environmental Committee Impact on Carbon Gas Emission Disclosure. The environmental committee is established to manage the company's environmental risks. The environmental risk management for companies' activities is an important factor that contains reputational risk and environmental threat to companies' legitimacy. Therefore, legitimacy and reputation management is the basis for the environmental committee whose major purpose is to reduce the environmental risk, including the carbon emission disclosure. (Yunus et al., 2016) stated that corporate environmental committees motivate companies to implement strategies and practices to measure and report carbon emission levels (Ashforth and Gibbs, 1990). Environmental committees manage strategies for environmental performance improvement and corporate carbon emissions disclosure to ensure that the disclosed information will not negatively affect companies' legitimacy and reputation Thus, the following hypothesis is suggested.

H3: Companies with environmental committees will have a higher level of carbon emission disclosure.

Foreign Diversity Impact on Carbon Gas Emission Disclosure. Board diversity based on nationalities has greater information and may be pressured by more stakeholder groups related to climate change and global warming issues. Companies with diverse management based on nationalities are expected to succeed in practicing carbon emission reduction and in disclosing information related to carbon emission (Kılıç and Kuzey, 2019). Companies with diverse boards will have a broader knowledge in the form of information and connections to identify the best strategy for managing potential conflicts and risks within the company, and some basis for legitimacy among stakeholders (Harjoto et al., 2014). Foreign diversity can provide a better assessment of the needs of diverse stakeholders which also influences decision-making. (K1lic and Kuzey, 2019) stated that the composition of board structures such as board national diversity has an influence on management decisions regarding carbon emission disclosure policies. Based on this notion, the following hypothesis is developed

H4: Companies with foreign diversity have a higher rate of carbon emission disclosure. 


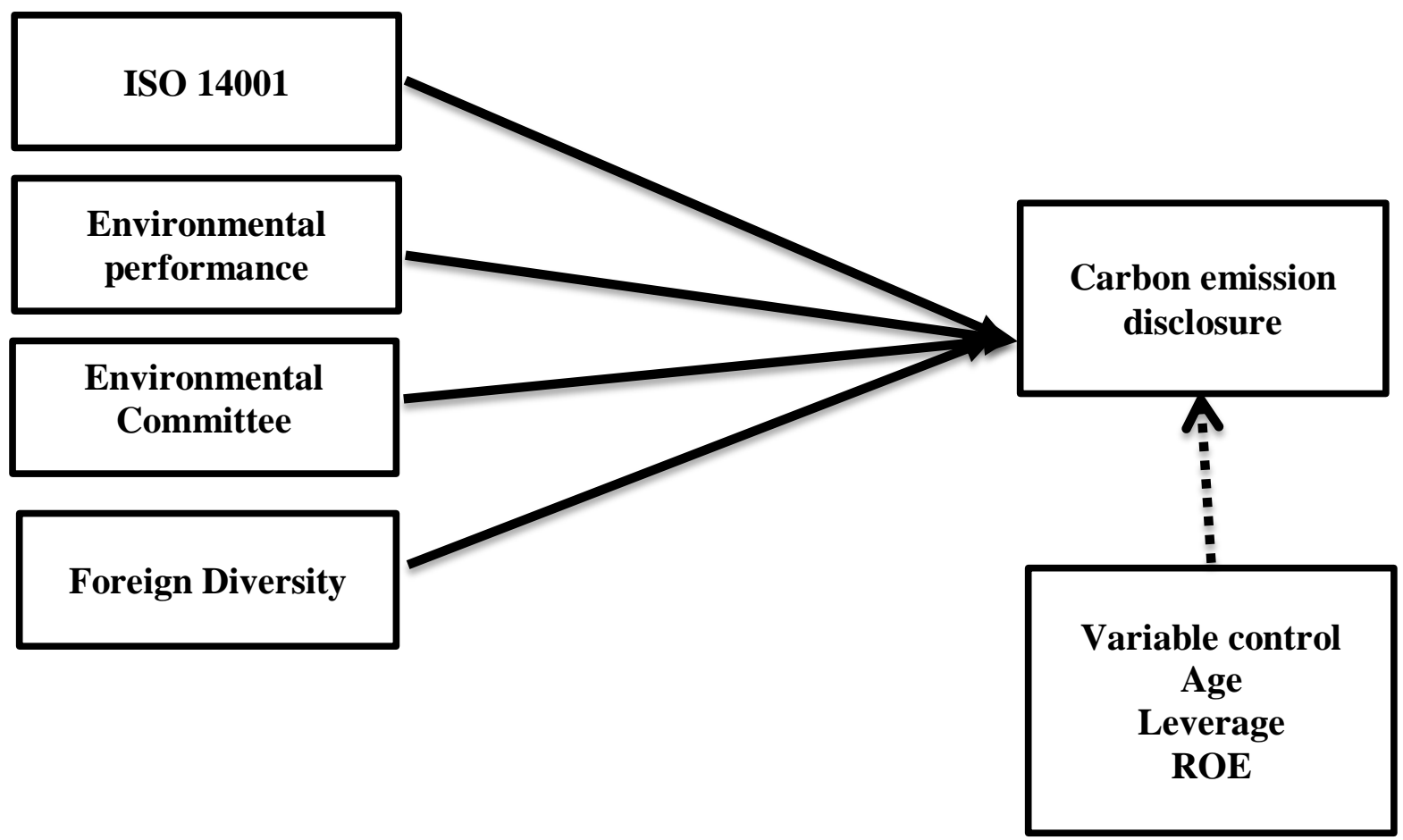

Figure 1. Research Model

\section{METHODS}

Types of research. This research uses an explanatory research approach that aims to explain the causal relationship between independent and dependent variables by testing the hypotheses. This research is a causality study because it is designed to identify causal relationships between variables. The causal relationship examined in this study is the effect of ISO 14001, environmental performance, environmental committee, and foreign diversity on carbon emission disclosure.

\section{Research variable}

Dependent variable: Carbon emission disclosure. Secondary data is used as a variable for the carbon emission disclosure. Carbon emission disclosure in this research are adopted from (Choi et al., 2013) and the checklist is based on information which consists of six categories of risks and climate change; calculation of greenhouse gas emissions; energy consumption; reduction of greenhouse gases; cost and accountability of carbon emissions; all further detailed into 18 index items of the Carbon Emission Disclosure Checklist. Each variable measurement is explained as follows. 
Table 1. Carbon Emission Disclosure Checklist

\begin{tabular}{|c|c|}
\hline Category & Item \\
\hline \multirow[t]{2}{*}{$\begin{array}{l}\text { Climate Change: } \\
\text { Risks and } \\
\text { opportunities }\end{array}$} & $\begin{array}{l}\text { CC1 - assessment or description of the risks (regulatory, physical, or general } \\
\text { opportunities) related to climate change and the actions being taken or will be } \\
\text { taken to manage the risks }\end{array}$ \\
\hline & $\begin{array}{l}\mathrm{CC} 2 \text { - assessment or description of current (and future) financial implications, } \\
\text { business implications, and climate change opportunities. }\end{array}$ \\
\hline \multirow[t]{7}{*}{$\begin{array}{l}\text { GHG (greenhouse } \\
\text { Gas) accounting }\end{array}$} & $\begin{array}{l}\text { GHG1 - description of the methodology used to calculate GHG emissions (e.g. } \\
\text { GHG protocol or ISO) }\end{array}$ \\
\hline & $\begin{array}{l}\text { GHG2 - there is external verification of the quantity of GHG emissions - if so } \\
\text { by whom and on what base. }\end{array}$ \\
\hline & GHG3 - total emisi GRK - metrik ton \\
\hline & $\begin{array}{l}\text { GHG4 - emitted CO2 disclosure of Scope } 1 \text { and 2, or Scope } 3 \text { direct GHG } \\
\text { emissions }\end{array}$ \\
\hline & GHG5 - disclosure of GHG emissions by source (eg coal, electricity, etc.) \\
\hline & GHG6 - GHG emission disclosure based on facility or segment level. \\
\hline & GHG7 - Comparison of GHG emissions with previous years. \\
\hline \multirow[t]{3}{*}{ Energy consumption } & EC1 - total energy consumed (eg tera-joules or map-joules) \\
\hline & EC2 -Quantification of energy used from renewable sources. \\
\hline & EC3 - disclosure based on type, facility, or segment \\
\hline \multirow[t]{4}{*}{ Reduction and cost } & RC1 - details of a plan or strategy to reduce GHG emissions. \\
\hline & RC2 - specification of GHG emission reduction target level and target year \\
\hline & $\begin{array}{l}\text { RC3 - emission reductions and associated costs or savings achieved to date as } \\
\text { a result of the reduction plan }\end{array}$ \\
\hline & RC4 - future emission costs are calculated in capital expenditure planning. \\
\hline \multirow[t]{2}{*}{$\begin{array}{l}\text { emission } \\
\text { accountability }\end{array}$} & $\begin{array}{l}\text { ACC1 - an indication of which board committee (or other executive } \\
\text { accountability body) has full responsibility for climate change-related actions }\end{array}$ \\
\hline & $\begin{array}{l}\text { ACC2 - a description of the mechanism by which the board (or other executive } \\
\text { body) reviews a company's progress on climate change. }\end{array}$ \\
\hline
\end{tabular}

Independent variable: The ISO 14001. Secondary data is used as a variable for ISO 14001. variable uses a dummy 1 for companies that are certified with ISO 14001 Environmental Management System. On the other hand, for companies that are yet to be certified with ISO 14001 (0), the measured variables are based on researches from (Yunus et al., 2016).

Independent variable: Environmental Performance variable is ranked based on the five colors of PROPER performance, i.e., Gold (excellent, score 5), Green (very good, score 4), Blue (good, score 3), Red (bad, score 2), Black (very bad, score 1), following the previous study by (Prafitri and Zulaikha, 2016). 
Independent variable: The environmental committee variable is evaluated using a variable dummy, with the value of 1 if the company has a board-level environmental committee and 0 for the opposite (Liao et al., 2015; Rankin et al., 2011; Yunus et al., 2016).

Independent variable: Foreign Diversity variable is approached using the number of foreign board members divided by the total number of members of the board of directors and commissioners of the company structure, adopting the research of (Kılıç and Kuzey, 2019).

Control variable: Age means The age of a company, whether the company has been established for a long time or has just been established, is measured by the year the company was founded, which was adopted from research by (Yunus et al., 2016). More matured firms are concerned about their reputation and, hence, they are more likely to concern about carbon emission disclosure (Khan et al., 2013)

Control variable: Leverage is the company's ability to use assets from creditor funds to create good returns and reduce costs. The ratio of leverage will be an important consideration for investors in making decisions (Darnall et al., 2010). The more a firm depends on funding from creditors, the more likely the firm is to address creditors' expectations regarding climate change and related carbon emission issues. Leverage variable is measured by total debt to total assets at the end of the fiscal year, as adopted from (Yunus et al., 2016); (Kilic and Kuzey, 2019)

Control variable: ROE is a profitability ratio to measure the extent of the company's capabilities in generating net returns for investors or owners of shareholder investment companies using their capital. Based on the research of (Dwyer et al., 2009), ROE can be formulated by the company's total net income to total equity. ROE provides a more financial view, the higher ROE ratios describe good financial performance company, good financial performance firm is more concerned about carbon emission disclosure.

Data Collection Method. The type of data in this study is quantitative data. The data source of this research is secondary data taken from companies' annual reports and sustainability reports.

Analysis Model. This study uses data analysis to test the hypotheses proposed by researchers in the form of multiple regression models with the following function form:

$$
\mathrm{CED}=\boldsymbol{\alpha}+\boldsymbol{\beta}_{1} \mathrm{ISO}+\boldsymbol{\beta}_{2} \mathrm{EP}+\boldsymbol{\beta}_{3} \mathrm{EC}+\boldsymbol{\beta}_{4} \text { Foreign }+\boldsymbol{\beta}_{5} \mathrm{AGE}+\boldsymbol{\beta}_{6} \mathrm{LEV}+\boldsymbol{\beta}_{7} \mathrm{ROE} \square \ldots \ldots
$$

Information

$\begin{array}{ll}\text { A } & \text { : Constants } \\ \text { ISO } & \text { : ISO } 14001 \\ \text { EP } & \text { : Environmental performance } \\ \text { EC } & \text { : Environmental committee } \\ \text { FOREIGN : Foreign diversity } \\ \text { AGE } & \text { : Age } \\ \text { LEV } & \text { : Leverage }\end{array}$


ROE : Return on equity

CED : Carbon Emission Disclosure

$\boldsymbol{\beta} \quad$ : Regression coefficient

Sampling Method. This study has adopted probability sampling focusing on stratified random sampling. With stratified sampling, the researcher can representatively sample even the smallest and most inaccessible subgroups in the population. This method allows the researcher to sample the rare extremes of the given population. The population of this study is all plantation companies listed on the Indonesian stock exchange from 2015 to 2019. A 77 companies sample was selected in this study.

\section{RESULT}

\section{Descriptive Statistics Analysis}

Table 2. Descriptive Statistics

\begin{tabular}{lccccccc}
\hline & ISO & EP & EC & Foreign & AGE & LEV & ROE \\
\hline minimum & 0 & 1 & 0 & 0 & 7 & 0.082 & -724.64 \\
\hline maximum & 1 & 4 & 1 & 0.38 & 113 & 1.65 & 3.5 \\
\hline S.deviation & 0.48 & 0.54 & 0.48 & 0.12 & 35.63 & 0.26 & 96.4 \\
\hline
\end{tabular}

Based on the above table shows that the minimum value of variable dummy ISO (ISO) 14001 that occurs is 0 and the maximum value is 1 with a standard deviation of 0.48 this explains that there are companies that do not have an ISO 14001 certificate. Variable EP (Environmental performance) has a minimum score of PROPER 1 and a maximum score of PROPER value 4 with a standard deviation of 0.54 that result shows no company has the excellent PROPER score of 5. The minimum value of variable dummy EC (Environmental committee) that occurs is 0 and the maximum value is 1 with a standard deviation of 0.48 this explains that there are companies that have no environmental committee. Variable Foreign (foreign diversity) result shows minimum value 0 it shows that there a company that has no foreign board and maximum ratio value is 0.38 with a standard deviation of 0.12 this explain that only a few companies have foreign boards. Variable control age has a minimum value of 7 and maximum value 113 with a standard deviation of 35.63 this explains that board diversity. variable control LEV (leverage) has a minimum ratio of $8 \%$ and a maximum ratio value of 1.65 with a standard deviation of 0.26 . variable control ROE (return on equity) has a minimum ratio of 0.082 and a maximum ratio value of 1.65 with a standard deviation of 0.26 .

Hypothesis Testing. The data analysis in this study uses multiple linear regression tests. The tests are carried out using a statistical application program, SPSS 26. The significance level used is $5 \%$. Before conducting a regression test, research data has passed the classical assumption test. 
Table 3. Hypothesis Test Results

\begin{tabular}{llllllll}
\hline & ISO & EP & EC & Foreign & AGE & LEV & ROE \\
\hline Coefficient & 0.16 & 0.094 & 0.534 & 0.383 & 0.01 & 0.041 & 0.01 \\
t-Value & $5.01 *$ & $3.68 *$ & $13.22 *$ & $2.60 *$ & 0.199 & 0.609 & 0.258 \\
Constant & $-0,246$ & & & & & & \\
Adj R & 0,89 & & & & & & \\
F-Value & $96.09 *$ & & & & & & \\
N & 77 & & & & & & \\
$*$ *ignificance level of $5 \%$ & & & & & &
\end{tabular}

Table 2 shows the hypothesis test results for the research model equation. The results of the T-test show that the t-value is greater than the table value of 1.66 and the coefficient value is positive on the independent variables of foreign diversity, ISO 14001, environmental performance rating (PROPER), and environmental committee and is significant at 0.05 level, which implied that the four hypotheses are accepted. The results show a positive influence of independent variables on the dependent variables. The control variables of companies' age (AGE), leverage (LEV), and ROE have significance levels above 0.05 or $5 \%$ which implied that the control variables are rejected.

The regression test results can be strengthened consistently, with the results of the $\mathrm{F}$ test where the $F$ value of 96.09 is greater than the $F$ table value of 2.51 with a significance level of 0.05 or $5 \%$. Adj value $R^{2}$ of 0.889 clearly shown that the independent variables can explain the dependent variable by $89 \%$, while the remaining $11 \%$ is explained by other variables.

\section{DISCUSSION}

ISO 14001 as a Predictor for Carbon Emission Disclosure. The regression hypothesis test results shown in Table 1 states that the application of ISO 14001 is significantly positive. Therefore, H1 is acceptable. ISO 14001 leads to a greater carbon emission disclosure. ISO 14001 certification is a tangible form of the company's efforts to be responsible for the company's environment. This is consistent with the research of (Orcos \& Palomas, 2019) which states that companies certified with ISO 14001 tend to lead to a higher level of environmental disclosure. Another requirement of ISO 14001 is to continuously update the Environmental Management System (EMS) to address recent environmental concerns related to carbon gas emissions. EMS implementation and certification help companies to integrate their environmental, health, and safety management systems, and in some cases, their environmental and quality management systems. ISO 14001 also helps companies to control and improve environmental impacts and helps companies gain legitimacy from external parties. The companies that certified for ISO 14001 can be a predictor for carbon emission disclosure because the requirement of ISO 14001 should report waste recycling, reduction of air and waste emissions, reuse of materials, energy and water conservation, and reduction of environmental and safety incidents, which are part of the indicator. disclosure of carbon emissions itself. 
Environmental Committee as a Predictor for Carbon Emission Disclosure. Hypothesis test results in Table 1, the environmental committee has a significant positive effect on carbon emission disclosure (H3). Company's that has environmental committee has a positive impact on carbon emission disclosure. The environmental committee or department is responsible for the formulation of a proactive environmental strategy (Darnall and Edwards Jr, 2006), and carbon emission disclosure (Ashforth and Gibbs, 1990). In line with the company's legitimacy theory, it also ensures that there is no possibility of a risk gap that can lead to legitimacy by stakeholders (Ferreira et al., 2013; Rankin et al., 2011; Yunus et al., 2016). (Liao et al., 2015) stated that environmental committees can balance the company's financial and non-financial interests with limited resources and moderate possible conflicting expectations of stakeholders with different interests. This is caused by the cost of carbon emission disclosure tends to be expensive, while stakeholders especially investors demand high profits. The environmental committee existed as a legitimacy gap between two different interests. (Rankin et al., 2011) stated that the environmental committee that implements environmental management strategies and policies to deal with carbon emissions as an initiation for environmental sustainability will get a place in the community.

Foreign Diversity as a Predictor for Carbon Emission Disclosure. Based on hypothesis test results, the foreign diversity effect is significant, therefore, $\mathrm{H} 4$ is acceptable. The presence of foreign boards in the companies has a positive impact on carbon emission disclosure and also can be a predictor of carbon emission disclosure. Foreign diversity can adopt the understanding they had when leading the previous company and then apply to the company they just led to motivate and report updated information related to carbon emissions disclosure. This is in line with the research conducted by (Kıliç and Kuzey, 2019). These findings also explain that companies with a high number of foreign boards are more likely to disclose information related to carbon emissions (Frias-Aceituno et al., 2013). A board comprising various nationalities can be subject to pressure related to environmental issues from many stakeholder groups because they tend to have greater information. The supervisory function of the foreign board is expected to improve management's ability to recognize the needs and interests of various stakeholder groups, especially in disclosing carbon emissions (Harjoto et al., 2019).

The hypothesis test results, Control variables are all rejected. The first control variable is the company's age The regression results of the control variable age are also rejected, which shows that the older company does not guarantee the disclosure of carbon emissions because the status of the report is voluntary, following the previous research by (Khan et al., 2013). The second control variable is leverage, leverage has no impact on carbon emission disclosure. This shows that companies with higher leverage value have heavy liabilities on debt and interest repayments will limit the company's ability to implement carbon emission reduction strategies (Clarkson et al., 2011). And the last control variable ROE also has no impact on carbon emission disclosure, The reason behind this result that companies will focus more on their business, not on the environmental impacts (Dwyer et al., 2009).

\section{CONCLUSION}

This study shows that the role of variable ISO 14001, environmental performance, environmental committee, and foreign diversity can be predictors of a level of carbon 
emission disclosure. These factors are a form of corporate legitimacy through stakeholders by increasing carbon emission disclosure. The limitation of this study is that companies that published carbon emission disclosures listed on the IDX are still relatively low and in a small number because the disclosure of carbon emissions is still voluntary and several companies do not meet the variable criteria so they are not included in the research data sample.

\section{REFERENCES}

Adams, C. A. (2002). Internal organizational factors influencing corporate social and ethical reporting. Accounting, Auditing \& Accountability Journal.

Aerts, W., and Cormier, D. (2009). Media legitimacy and corporate environmental communication. Accounting, Organizations and Society, 34(1), 1-27.

Ashforth, B. E., and Gibbs, B. W. (1990). The double-edge of organizational legitimation. Organization Science, 1(2), 177-194.

Bansal, P., and Hunter, T. (2003). Strategic explanations for the early adoption of ISO 14001. Journal of business ethics, 46(3), 289-299.

Barako, D. G., and Brown, A. M. (2008). Corporate social reporting and board representation: evidence from the Kenyan banking sector. Journal of Management \& Governance, 12(4), 309.

Blackman, A. (2012). Does eco-certification boost regulatory compliance in developing countries? ISO 14001 in Mexico. Journal of Regulatory Economics, 42(3), 242-263.

Choi, B. B., Lee, D., and Psaros, J. (2013). An analysis of Australian company carbon emission disclosures. Pacific Accounting Review.

Clarkson, P. M., Li, Y., Richardson, G. D., and Vasvari, F. P. (2008). Revisiting the relation between environmental performance and environmental disclosure: An empirical analysis. Accounting, Organizations and Society, 33(4-5), 303-327.

Coffey, B. S., and Wang, J. (1998). Board diversity and managerial control as predictors of corporate social performance. Journal of business ethics, 17(14), 1595-1603.

Collier, P. M. (2008). Stakeholder accountability: A field study of the implementation of a governance improvement plan. Accounting, Auditing \& Accountability Journal, 21(7), 933-954.

Darnall, N., Henriques, I., and Sadorsky, P. (2010). Adopting proactive environmental strategy: The influence of stakeholders and firm size. Journal of management studies, 47(6), 1072-1094.

Dawkins, C., and Fraas, J. W. (2011). Coming clean: The impact of environmental performance and visibility on corporate climate change disclosure. Journal of business ethics, 100(2), 303-322.

Di Giacomo, N., Guthrie, J., and Farneti, F. (2017). Environmental management control systems for carbon emissions. PSU Research Review.

Dowling, J., and Pfeffer, J. (1975). Organizational legitimacy: Social values and organizational behavior. Pacific sociological review, 18(1), 122-136.

Dwyer, R., Lamond, D., Prado- Lorenzo, J. M., Rodríguez- Domínguez, L., GallegoÁlvarez, I., and García- Sánchez, I. M. (2009). Factors influencing the disclosure of greenhouse gas emissions in companies world- wide. Management Decision.

Estélyi, K. S., and Nisar, T. M. (2016). Diverse boards: Why do firms get foreign nationals on their boards? Journal of Corporate Finance, 39, 174-192. 
Ferreira, J. J., Vila, J. E., Mariussen, A., Kuo, L., and Chen, V. Y.-J. (2013). Is environmental disclosure an effective strategy on establishment of environmental legitimacy for organization? Management Decision.

Freedman, M., and Jaggi, B. (2011). Global warming disclosures: impact of Kyoto protocol across countries. Journal of International Financial Management \& Accounting, 22(1), 46-90.

Gray, R., Kouhy, R., and Lavers, S. (1995). Corporate social and environmental reporting. Accounting, Auditing \& Accountability Journal.

Guthrie, J., and Parker, L. D. (1989). Corporate social reporting: a rebuttal of legitimacy theory. Accounting and business research, 19(76), 343-352.

Harjoto, M. A., Laksmana, I., and wen Yang, Y. (2019). Board nationality and educational background diversity and corporate social performance. Corporate Governance: The International Journal of Business in Society.

Hettige, H., Dasgupta, S., and Wheeler, D. (2000). What improves environmental compliance? Evidence from Mexican industry. Journal of Environmental Economics and Management, 39(1), 39-66.

Ikram, M., Mahmoudi, A., Shah, S. Z. A., and Mohsin, M. (2019). Forecasting number of ISO 14001 certifications of selected countries: application of even GM (1, 1), DGM, and NDGM models. Environmental Science and Pollution Research, 26(12), 1250512521.

INDONESIA, M. L. H. R. (2014). Peraturan Menteri Lingkungan Hidup Republik Indonesia Nomor 7 tahun 2014 tentang Kerugian Lingkungan Hidup Akibat Pencemaran dan/Atau Kerusakan Lingkungan Hidup.

Iriyanto, F. N., and Nugroho, P. I. (2014). Pengaruh Kinerja Lingkungan terhadap Praktik Pengungkapan Sustainability Report dan Kinerja Ekonomi. Dinamika Akuntansi Keuangan dan Perbankan, 3(1).

ISO. (2015). ISO 14001: Environmental Management Systems-Requirements with Guidance for Use: ISO.

Iswati, S. (2017). Carbon Accounting Reflection as a Response to Face the Climate Change. Paper presented at the 1st International Conference Postgraduate School Universitas Airlangga:" Implementation of Climate Change Agreement to Meet Sustainable Development Goals"(ICPSUAS 2017).

Kalu, J. U., Buang, A., and Aliagha, G. U. (2016). Determinants of voluntary carbon disclosure in the corporate real estate sector of Malaysia. Journal of environmental management, 182, 519-524.

Khan, A., Muttakin, M. B., and Siddiqui, J. (2013). Corporate governance and corporate social responsibility disclosures: Evidence from an emerging economy. Journal of business ethics, 114(2), 207-223.

Kılıç, M., and Kuzey, C. (2019). The effect of corporate governance on carbon emission disclosures. International Journal of Climate Change Strategies and Management.

Liao, L., Luo, L., and Tang, Q. (2015). Gender diversity, board independence, environmental committee and greenhouse gas disclosure. The British Accounting Review, 47(4), 409-424.

Lindawati, A. S. L., and Puspita, M. E. (2015). Corporate Social Responsibilty: Implikasi Stakeholder dan Legitimacy Gap dalam Peningkatan Kinerja Perusahaan. Jurnal Akuntansi Multiparadigma, 6(1), 157-174. 
Lindblom, C. K. (1994). The implications of organizational legitimacy for corporate social performance and disclosure. Paper presented at the Critical Perspectives on Accounting Conference, New York, 1994.

Luo, L., Tang, Q., and Lan, Y. C. (2013). Comparison of propensity for carbon disclosure between developing and developed countries. Accounting Research Journal.

Orcos, R., and Palomas, S. (2019). The impact of national culture on the adoption of environmental management standards. Cross Cultural \& Strategic Management.

Prafitri, A., and Zulaikha, Z. (2016). Analisis Pengungkapan Emisi Gas Rumah Kaca. Jurnal Akuntansi Dan Auditing, 13(2), 155-175.

Quazi, H. A., Khoo, Y.-K., Tan, C.-M., and Wong, P.-S. (2001). Motivation for ISO 14000 certification: development of a predictive model. Omega, 29(6), 525-542.

Rankin, M., Windsor, C., and Wahyuni, D. (2011). An investigation of voluntary corporate greenhouse gas emissions reporting in a market governance system. Accounting, Auditing \& Accountability Journal.

Sartor, M., Orzes, G., Touboulic, A., Culot, G., and Nassimbeni, G. (2019). ISO 14001 standard: Literature review and theory-based research agenda. Quality Management Journal, 26(1), 32-64.

Sprengel, D. C., \& Busch, T. (2011). Stakeholder engagement and environmental strategythe case of climate change. Business Strategy and the Environment, 20(6), 351-364.

Stern, N. (2008). Key elements of a global deal on climate change.

Vílchez, V. F. (2017). The dark side of ISO 14001: The symbolic environmental behavior. European Research on Management and Business Economics, 23(1), 33-39.

Weinhofer, G., and Hoffmann, V. H. (2010). Mitigating climate change-how do corporate strategies differ? Business Strategy and the Environment, 19(2), 77-89.

Yunus, S., Elijido-Ten, E., and Abhayawansa, S. (2016). Determinants of carbon management strategy adoption: Evidence from Australia's top 200 publicly listed firms. Managerial Auditing Journal, 31(2), 156-179. 